\title{
PENINGKATAN KOMPETENSI DAN KREATIVITAS GURU SMP MELALUI PELATIHAN PEMBUATAN SOAL-SOAL BERBASIS HIGHER ORDER THINKING SKILL (HOTS)
}

\section{IMPROVING THE COMPETENCE AND CREATIVITY OF JUNIOR HIGH SCHOOL'S TEACHERS BASED ON HIGHER ORDER THINKING SKILL (HOTS) QUESTIONS}

\author{
Wulandari $^{1)}$, Marhami $^{2)}$, Rohantizani $^{3)}$, Muliana $^{4)}$ \\ ${ }^{1,2,3,4}$ Prodi Pendidikan Matematika, Universitas Malikussaleh \\ ${ }^{1}$ Email: wulandari@unimal.ac.id
}

\begin{abstract}
Abstrak: Pengabdian kepada masyarakat ini bertujuan untuk meningkatkan kompetensi dan kreativitas guru-guru SMP di Aceh Utara dalam mengimplementasikan pembelajaran matematika melalui pembuatan soal-soal berbasis HOTS (Higher Order Thinking Skill). Kegiatan pengabdian kepada masyarakat ini terdiri dari (1) Pengenalan soal HOTS sebagai Alat Evaluasi, (2) Mendesain Soal Hots, (3) Praktik pembuatan soal HOTS pada materi Aljabar, Statistika, dan Geometri. Metode yang digunakan dalam kegiatan ini adalah metode ceramah, dialogis, dan pelatihan. Kegiatan ini diharapkan bermanfaat bagi guru-guru SMP di Aceh Utara dan berdampak pada terjadinya peningkatan kompetensi, kreativitas, dan professional guru-guru SMP di Aceh Utara. Dari hasil pelaksanaan kegiatan pengabdian kepada masyarakat ini, diperoleh hasil bahwa: (1) Bertambahnya wawasan guru-guru SMP di Aceh Utara tentang pembuatan soal-soal matematika berbasis HOTS, (2) Meningkatnya pemahaman guru-guruSMP di Aceh Utara dalam memecahkan masalah matematis yang menuntut berpikir tingkat tinggi, (3) Meningkatnya kreativitas guru-guru SMP di Aceh Utara dalam membuat perencanaan pembelajaran matematis yang berbasis HOTS.
\end{abstract}

Kata Kunci: Kompetensi Guru, Kreativitas Guru, HOTS.

Abstract: This dedication aims to increase the competence and creativity of junior high school teachers in North Aceh in implementing mathematics learning based on HOTS (Higher Order Thinking Skill) questions. This activity consists of (1) Introduction of HOTS questions as an Evaluation Tools, (2) Designing HOTS Questions, (3) Practicing in creating HOTS questions on Algebra, Statistics, and Geometry subject. The methods used in this activity are direct, dialogic, and training methods. This activity is supposed to increase the competence, creativity and professionalism of junior high school teachers in North Aceh. The results show that: (1) The perception of junior high school teachers in North Aceh regarding HOTS math problems is increasing, (2) The understanding of Junior High School teachers in North Aceh in solving mathematical problems of highlevel thinking is increasing, (3) The creativity of junior high school teachers in North Aceh in making mathematical learning plans based on HOTS is increasing.

Keywords: Teacher's Competence, Teacher's Creativity, HOTS. 


\section{INTEGRITAS : Jurnal Pengabdian}

Vol 4, No 2, Desember 2020

ISSN 2580 - 7978 (cetak) ISSN 2615 - 0794 (online)

\section{PENDAHULUAN}

Dalam arti luas, guru merupakan suatu profesi yang artinya suatu jabatan atau pekerjaan yang memerlukan keahlian khusus sebagai guru (Uno, 2007:15). Untuk menjadi guru diperlukan syarat-syarat untuk menguasai seluk-beluk pendidikan dan pengajaran dengan berbagai ilmu pengetahuan lainnya, yang perlu dibina dan dikembangkan melalui masa pendidikan tertentu.

Berdasarkan Undang-Undang Nomor 14 tahun 2005 tentang Guru dan Dosen dinyatakan bahwa "Kompetensi guru meliputi kompetensi pedagogic, kompetensi kepribadian, kompetensi sosial, dan kompetensi professional yang diperoleh melalui pendidikan profesi”. Dengan demikian seorang guru harus memiliki kompetensi, yaitu pengetahuan, keterampilan, dan nilai-nilai dasar yang refleksinya dalam kebiasaan berpikir dan bertindak. Sebab kompetensi inilah yang juga akan menentukan keberhasilan anak didik dalam melaksanakan proses belajar mengajar.

Selain memliki kompetensi, seorang guru juga harus memiliki kreativitas dalam melakukan pembelajaran, baik di dalam kelas maupun via online. Menurut Moustakis (dalam Munandar, 2004: 18), kreativitas adalah pengalaman mengekspresikan dan mengaktualisasikan identitas individu dalam bentuk terpadu dalam hubungan dengan diri sendiri dengan alam dan dengan orang lain. Dengan demikian, seorang guru harus dapat mengekspresikan dan mengaktualisasikan segala daya yang dimilikinya untuk membuat sebuah pembelajaran yang menarik dan disenangi siswa.

Kegiatan pembelajaran pada level HOTS (Higher Order Thinking Skill) merupakan satu kegiatan pembelajaran yang menuntut kompetensi dan kreativitas guru. Dimana guru harus mampu menciptakan sebuah permasalahan yang menggali nalar siswa dalam pemecahan masalah di tingkat berpikir yang lebih tinggi yaitu menganalisis dan mengkreasi. Kegiatan pembelajaran pun diharapkan didesain secara kolaboratif untuk melatih kerjasama, kemampuan berkomunikasi, kemampuan berargumentasi, serta kemampuan mengendalikan emosi. Dengan demikian, di samping belajar materi pelajaran, siswa pun diberikan penanaman 


\section{INTEGRITAS : Jurnal Pengabdian}

Vol 4, No 2, Desember 2020

ISSN 2580 - 7978 (cetak) ISSN 2615 - 0794 (online)

pendidikan karakter dan literasi sebagaimana yang saat ini diamanatkan oleh Kemdikbud dimana kedua hal tersebut harus diintegrasikan pada kegiatan pembelajaran.

HOTS awalnya dikenal dari konsep Benjamin S. Bloom, dkk dalam bukunya yang berjudul Taxonomy of Educational Objectives: The Classification of Educational Goals (1956) yang mengategorikan berbagai tingkat pemikiran bernama Taksonomi Bloom, mulai dari yang terendah hingga yang tertinggi. Konsep ini merupakan tujuan-tujuan pembelajaran yang terbagi ke dalam tiga ranah, yaitu kognitif (keterampilan mental seputar pengetahuan), afektif (sisi emosi seputar sikap dan perasaan), dan psikomotorik (kemampuan fisik seperti keterampilan). Soal HOTS mendorong siswa untuk melakukan penalaran tingkat tinggi sehingga tidak terpaku hanya pada satu pola jawaban yang dihasilkan dari proses menghafal, tanpa mengetahui konsep ilmunya. HOTS merupakan salah satu tuntutan keterampilan dalam pembelajaran abad 21, yaitu berpikir kritis, kreatif, kolaboratif, dan komunikatif.

Pada prakteknya, penerapan pembelajaran HOTS bukanlah hal yang mudah dilaksanakan oleh guru. Hal ini sesuai dengan hasil wawancara yang telah dilakukan kepada salah seorang guru MTsN 2 Dewantara, Aceh Utara yang mengatakan bahwa guru-guru di MTsN 2 Dewantara memerlukan banyak pelatihan soal-soal berbasis HOTS. Hal ini disebabkan karena kurangnya kreativitas guru dalam mengembangkan kompetensi keilmuwan yang dimiliki akibat kurangnya pelatihan ataupun perhatian dalam pengembangan diri bagi guru, baik dari pihak sekolah maupun pihak pemerintah setempat. Hal ini mengakibatkan guru tidak mampu bersaing dalam membuat soal-soal HOTS dan hanya menggunakan soal-soal rutin saja. Padahal kemampuan guru dalam mengembangkan soal-soal HOTS juga akan ikut mengembangkan kemampuan siswa untuk berpikir secara kritis dan analitis.

Kemampuan guru dalam menyusun skenario pembelajaran dan penilaian HOTS harus sama-sama ditingkatkan. Untuk itu, forum ilmiah seperti pelatihan pembuatan soal-soal HOTS menjadi sarana yang sangat strategis untuk 


\section{INTEGRITAS : Jurnal Pengabdian}

Vol 4, No 2, Desember 2020

ISSN $2580-7978$ (cetak) ISSN 2615-0794 (online)

mewujudkannya. Pada kegiatan tersebut disamping para guru mendapatkan wawasan baru dari pakar, juga dapat berdiskusi, sekaligus praktek menerapkan pembelajaran dan penilaian HOTS. Untuk mewujudkan hal tersebut, dalam menerapkan Tridharma Perguruan Tinggi khususnya dalam pengabdian kepada masyarakat, penulis akan memberikan pelatihan tentang soal-soal HOTS. Tujuannya untuk meningkatkan kompetensi dan kreativitas guru dalam pembuatan soal-soal berbasis HOTS.

Soal-soal HOTS bukan berarti soal yang sulit, redaksinya panjang dan berbelit-belit sehingga banyak membuang banyak waktu membacanya dan sekaligus memusingkan siswa, tetapi soal tersebut disusun secara proporsional dan sistematis untuk mengukur Indikator Ketercapaian Kompetensi (IKK) secara efektif serta memiliki kedalaman sehingga siswa pun terangsang untuk menjawab bukan hanya "menghitung kancing" atau menjawab secara asal-asalan. Jawaban soal uraian disamping tertutup juga dapat bersifat terbuka agar siswa mampu mengonstruksi jawabannya dengan bebas.

Oleh karena itu berdasarkan hasil analisis situasi dan wawancara dengan guru SMP di Aceh Utara dapat dirumuskan beberapa masalah, yaitu:

1. Kurangnya kompetensi guru dalam membuat soal-soal HOTS

2. Kurangnya kreativitas guru dalam mengembangkan soal-soal yang berbasis HOTS.

Berdasarkan permasalahan yang dihadapi guru SMP di Aceh Utara maka solusi yang ditawarkan pengusul melalui program pengabdian masyarakat ini yaitu pelatihan "Peningkatan Kompetensi dan Kreativitas Guru SMP Melalui Pelatihan Pembuatan Soal-Soal Berbasis Higher Order Thinking Skill (HOTS)". Sehingga yang dengan solusi ini, diharapkan:

1. Para guru SMP di Aceh Utara mampu dan berkompeten untuk membuat soalsoal HOTS.

2. Para guru SMP di Aceh Utara mampu mengembangkan kreativitasnya dalam membuat soal-soal berbasis HOTS.

Adapun manfaat dari kegiatan ini adalah: 


\section{INTEGRITAS : Jurnal Pengabdian}

Vol 4, No 2, Desember 2020

ISSN $2580-7978$ (cetak) ISSN 2615 - 0794 (online)

1. Bagi guru, dapat meningkatkan kompetensi dan kreativitas guru dalam pembuatan soal-soal HOTS

2. Bagi siswa, memiliki gambaran soal-soal HOTS dan cara penyelesaiannya sehingga mampu membantu siswa baik dalam menyelesaikan ujian nasional, masuk PTN, ataupun mengikuti berbagai olimpiade.

3. Bagi peneliti, dapat memberikan kontribusi yang bermanfaat bagi pengembangan guru dan peserta didik.

\section{METODE}

Berdasarkan latar belakang masalah dapat diidentifikasi permasalahan yang dihadapi guru SMP di Aceh Utara sehingga dapat dirumuskan permasalahan, yaitu bagaimana meningkatkan kompetensi dan kreativitas guru SMP di Aceh Utara. Adapun solusi yang ditawarkan adalah melalui workshop pengenalan Soal-Soal Berbasis Higher Order Thinking Skill (HOTS), dilanjutkan mendesain soal-soal HOTS, dan diakhiri dengan praktek pembuatan soal HOTS pada materi Aljabar, Statistik, dan Geometri.

Metode yang digunakan adalah metode ceramah, dialogis, dan pelatihan. Metode ceramah digunakan untuk menyampaikan teori mengenai soal-soal berbasis HOTS, dimana pada tahap ini tim pengabdian kepada masyarakat menyajikan materi sebagai awal pengenalan soal-soal HOTS. Selanjutnya dilaksanakan pelatihan dengan melibatkan peserta secara langsung, yaitu guruguru SMP Di Aceh Utara yang berjumlah 36 orang, untuk membuat dan mengembangkan soal-soal berbasis HOTS. Dan diakhiri dengan dialog atau diskusi untuk mengatasi permasalahan yang dialami peserta pada saat pelatihan berlangsung.

\section{HASIL DAN PEMBAHASAN}

Kegiatan pengabdian kepada masyarakat ini dilaksanakan pada hari Sabtu, 14 November 2020 bertempat di Lhokseumawe, yang diikuti oleh 36 peserta yang merupakan guru SMP yang ada di Aceh Utara, antara lain MTsS Jabal Nur, SMPN 1 Dewantara, SMP IT Al Markazul Islam, SMPN 1 Muara Batu, SMPN 1 Samudera, MTsN 2 Aceh Utara, MTsN 2 Aceh Utara, MTsN 1 Kota 
INTEGRITAS : Jurnal Pengabdian

Vol 4, No 2, Desember 2020

ISSN $2580-7978$ (cetak) ISSN 2615 - 0794 (online)

Lhokseumawe, SMPN 1 Syamtalira Bayu, SMPN 2 Meurah Mulia, MTsN 4 Aceh Utara, MTsS Syamsuddhuha, SMPN 1 Syamtalira B

Gambar 1 berikut menyajikan foto peserta pada waktu mengikuti kegiatan pengabdian kepada masyarakat pada materi pengenalan soal-soal HOTS

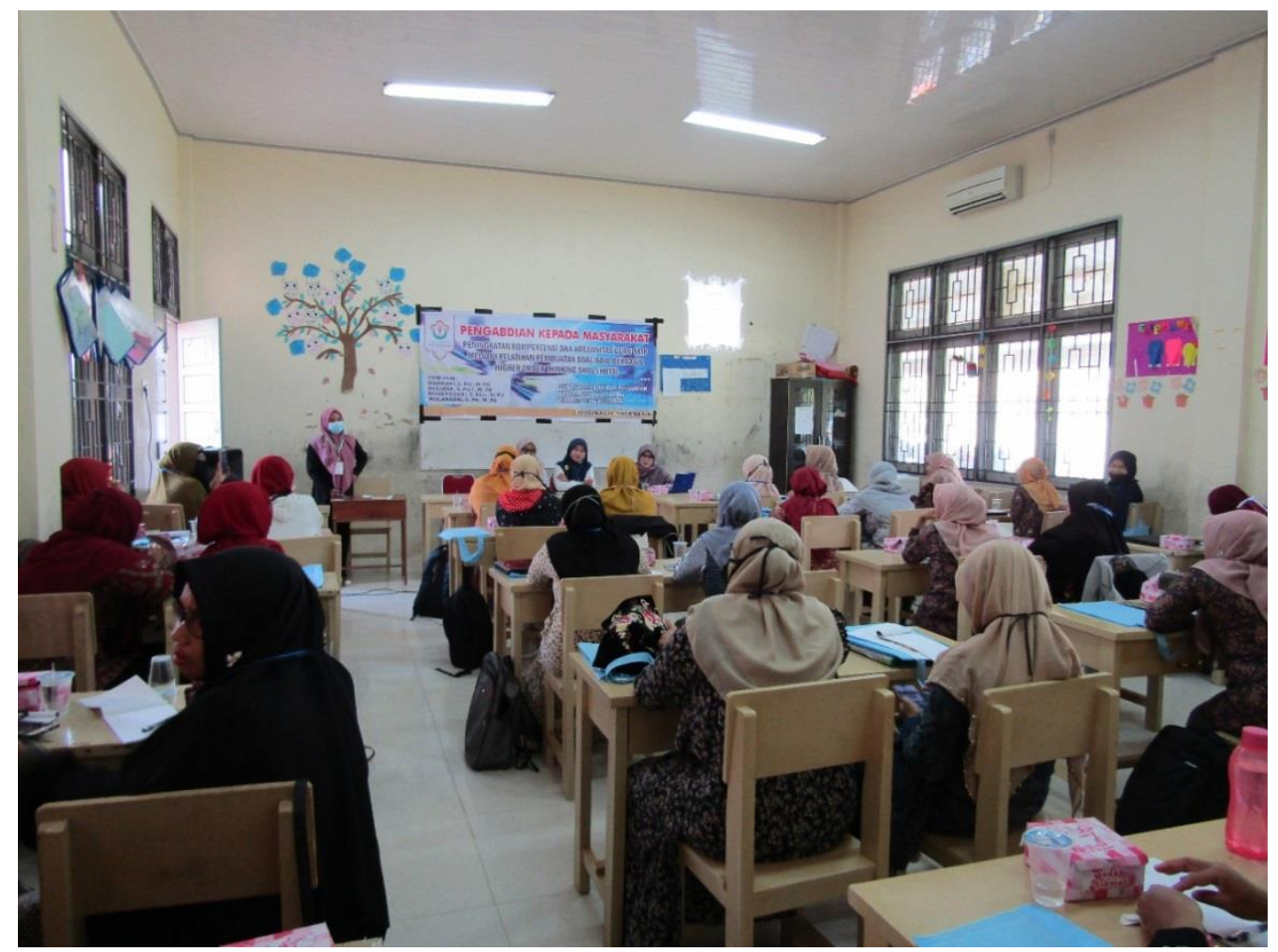

Gambar 1. Penyajian Materi Pengenalan Soal HOTS

Kegiatan diawali dengan penyajian materi tentang pengenalan soal berbasis HOTS sebagai alat evaluasi. Inti dari materi pertama yang diberikan ditinjau dari taksonomi Bloom yang direvisi oleh Anderson, ranah kognitif terbagi menjadi enam tingkat, yaitu: mengingat (C1), memahami (C2), menerapkan (C3), menganalisis (C4), mengevaluasi (C5), dan mencipta/ kreasi (C6).

Keterampilan berfikir tingkat tinggi diartikan dalam berbagai sudut pandang yang berbeda menurut para ahli. Higher Order Thinking Skill (HOTs) dirumuskan pertama kali oleh penulis dari Dusquance University, yaitu Susan M Brookhart dalam bukunya yang berjudul 'How to Assess Higher-order Thinking Skills in Your Classroom" (Sofyan dalam Rohim, 2019) dimana dia mendefinisikan bahwa model ini sebagai metode untuk berfikir kritis, transfer pengetahuan dan 


\section{INTEGRITAS : Jurnal Pengabdian}

Vol 4, No 2, Desember 2020

ISSN $2580-7978$ (cetak) ISSN 2615 - 0794 (online)

pemecahan masalah. Karakteristik soal berbasis HOTs yaitu (1) dapat mengukur keterampilan berfikir tingkat tinggi, (2) menggunakan permasalahaan yang menarik atau permasalahan dalam kehidupan sehari-hari, dan (3) digunakannya jenis soal dengan bentuk yang bermacam-macam (Ariyana \& Bestary, 2018).

Karakteristik di atas menjadi pegangan seorang guru dalam menyusun soalsoal berbasis HOTs, sehingga ada strategi-strategi tertentu dalam menyusun soal tersebut. Strategi menyusun soal berbasis HOTs meliputi beberapa langkah yaitu (1) melakukan analisis terhadap kompetensi dasar, (2) membuat kisi-kisi soal, (3) menggunakan masalah yang menyangkut kehidupan sehari-hari, (4) menyusun butir soal dan (5) membuat pedoman penskoran (Fanani, 2018).

Gambar 2 berikut memperlihatkan foto kegiatan penyajian materi mendesain soal-soal matematika berbasis HOTS.

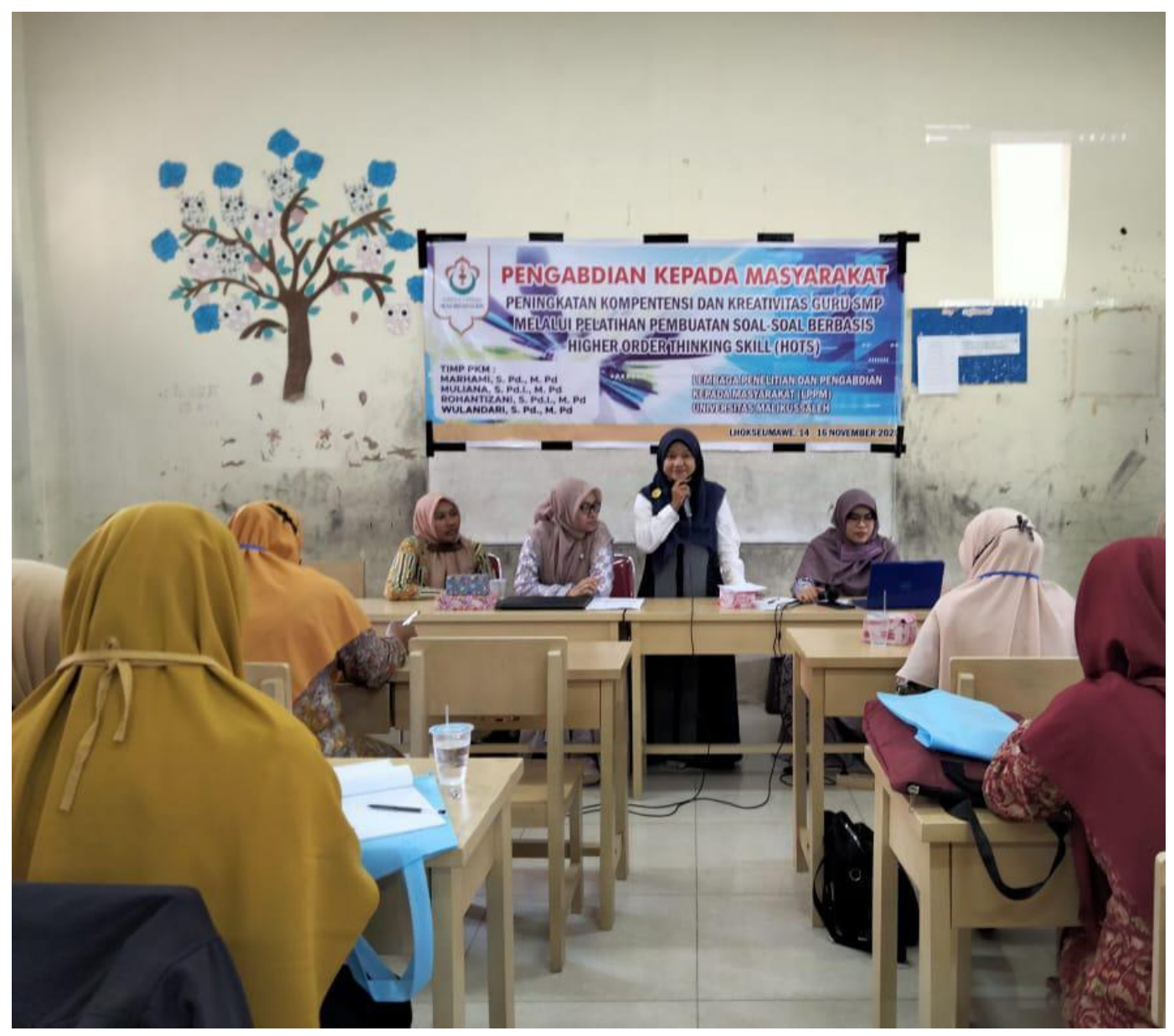

Gambar 2. Penyajian Materi Mendesain Soal HOTS 


\section{INTEGRITAS : Jurnal Pengabdian}

Vol 4, No 2, Desember 2020

ISSN 2580 - 7978 (cetak) ISSN 2615 - 0794 (online)

Penyajian materi ke - 2 tentang mendesain pembuatan soal-soal matematika berbasis HOTS. Sebelum mendesain soal HOTS, guru harus mengetahui bentukbentuk soal HOTS yaitu dapat berupa pilihan ganda, menjodohkan, isian singkat, uraian, unjuk kerja, serta portofolio. Dalam mendesain soal-soal HOTS juga perlu memahami karakteristik soal HOTS yaitu (1) harus memiliki stimulus, yaitu dapat berupa wacana, ilustrasi, gambar, tabel, data, grafik, informasi, diagram, dll yang menarik, (2) stimulus sangat dianjurkan diambil dari konteks dunia nyata/ kehidupan sehari-hari dan kebaruan, (3) pertanyaan yang diberikan menuntut proses berpikir secara kritis, logis, metakognisi, dan kreatif, (4) tetap berlaku kaidah-kaidah penulisan soal Pilihan ganda/ uraian/ isian.

Bentuk kegiatan selanjutnya adalah memberikan aktivitas kepada guru SMP di Aceh Utara untuk mendesain soal-soal matematika berbasis HOTS. Dari desain yang diberikan oleh guru-guru tersebut, ada yang telah memahami bentuk-bentuk soal HOTS, namun ada juga yang masih memberikan soal-soal yang berbasis LOTS.

Gambar 3 berikut memperlihatkan salah satu desain guru SMP yang memuat soal berbasis HOTS.

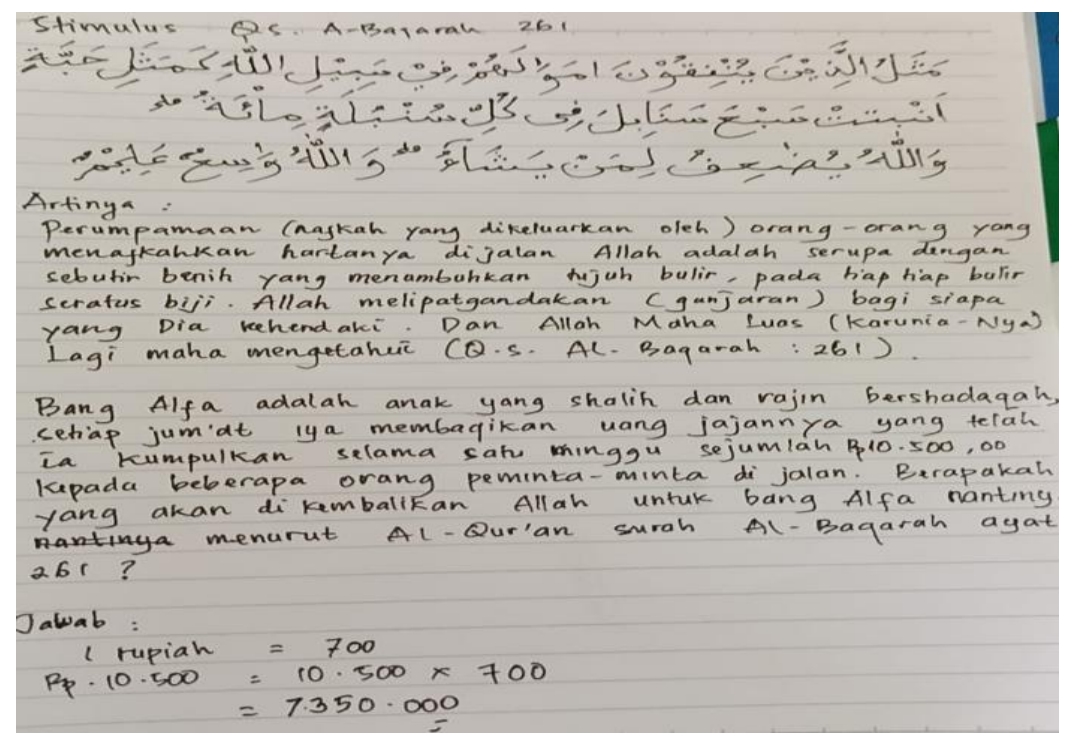

Gambar 3. Soal HOTS yang didesain Guru SMP 


\section{INTEGRITAS : Jurnal Pengabdian}

Vol 4, No 2, Desember 2020

ISSN $2580-7978$ (cetak) ISSN 2615 - 0794 (online)

Gambar 4 memperlihatkan kegiatan diskusi atau Tanya jawab peserta terkait soal-soal berbasis HOTS.

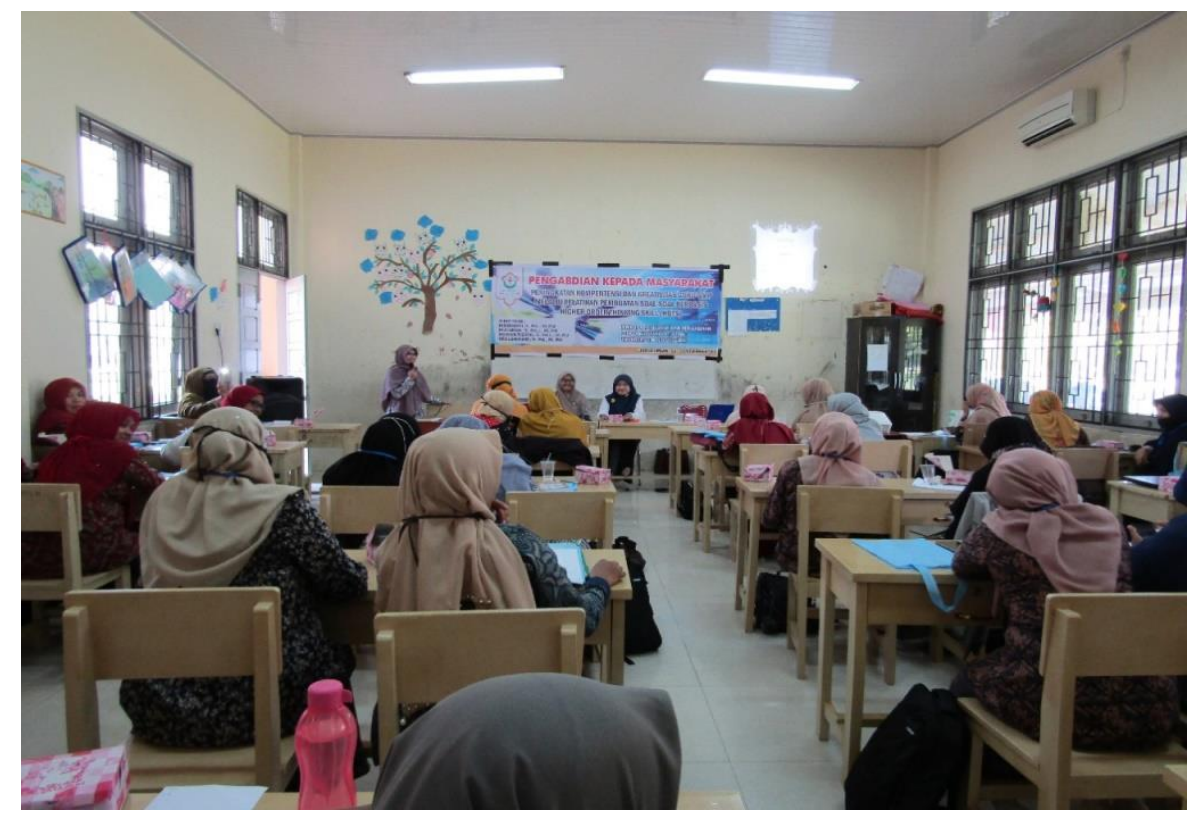

Gambar 4. Kegiatan diskusi dan Tanya jawab

Kegiatan selanjutnya adalah diskusi atau Tanya jawab peserta terkait soalsoal berbasis HOTS. Kegiatan ini berjalan dengan lancar, terlihat dari antusias peserta yang banyak memberikan pertanyaan terkait soal-soal HOTS, diantaranya bagaimana mengubah bentuk soal rutin menjadi soal HOTS, bagaimana menerapkan soal-soal HOTS pada anak pedalaman, yang mengerjakan soal-sola rutin saja masih belum lancar, serta bagaimana menerapkan soal-soal HOTS pada anak-anak yang belum memahami bahasa Indonesia dengan baik dan benar.

Peserta juga diberi angket penilaian tentang pemahaman peserta terhadap HOTS, baik sebelum maupun sesudah pelatihan. Berikut hasil angket penilaian peserta tentang pemahaman peserta terhadap HOTS. 
INTEGRITAS : Jurnal Pengabdian

Vol 4, No 2, Desember 2020

ISSN 2580 - 7978 (cetak) ISSN 2615 - 0794 (online)

Tabel 1. Hasil Angket Peserta tentang HOTS

\begin{tabular}{|c|c|c|c|c|c|}
\hline \multirow[t]{2}{*}{ No } & \multirow[t]{2}{*}{ Pertanyaan } & \multicolumn{2}{|c|}{ Sebelum Pelatihan } & \multicolumn{2}{|c|}{ Setelah Pelatihan } \\
\hline & & Jawaban & Persentase & Jawaban & Persentase \\
\hline 1 & $\begin{array}{lr}\text { Apakah } & \text { Bapak/Ibu } \\
\text { memahami apa yang } \\
\text { dimaksud dengan } & \text { soal-soal } \\
\text { berbasis HOTS? }\end{array}$ & $\begin{array}{l}\text { a. Sudah paham } \\
\text { b. Kurang paham } \\
\text { c. Tidak paham }\end{array}$ & $\begin{array}{c}16,7 \% \\
77,8 \% \\
5,5 \%\end{array}$ & $\begin{array}{l}\text { a. sudah paham } \\
\text { b. kurang paham } \\
\text { c. tidak paham }\end{array}$ & $\begin{array}{l}91 \% \\
6,2 \% \\
2,8 \%\end{array}$ \\
\hline 2 & $\begin{array}{l}\text { Apakah bapak/ibu bisa } \\
\text { membedakan soal-soal } \\
\text { berbasis HOTS dengan soal- } \\
\text { soal biasa? }\end{array}$ & $\begin{array}{l}\text { a. Ya } \\
\text { b. Masih bingung } \\
\text { c. Tidak }\end{array}$ & $\begin{array}{c}16,7 \% \\
5,5 \% \\
77,8 \%\end{array}$ & $\begin{array}{l}\text { a. Ya } \\
\text { b. Masih bingung } \\
\text { c. Tidak }\end{array}$ & $\begin{array}{c}83,33 \% \\
11,1 \% \\
5,6 \%\end{array}$ \\
\hline 3 & $\begin{array}{lr}\text { Apakah } & \text { Bapak/Ibu } \\
\text { mengetahui } & \text { bagaimana } \\
\text { karakteristik } & \text { soal berbasis } \\
\text { HOTS ? } & \end{array}$ & $\begin{array}{l}\text { a. Ya } \\
\text { b. Kurang tahu } \\
\text { c. Tidak tahu }\end{array}$ & $\begin{array}{c}2,8 \% \\
91,7 \% \\
5,5 \%\end{array}$ & $\begin{array}{l}\text { a. Ya } \\
\text { b. Kurang tahu } \\
\text { c. Tidak tahu }\end{array}$ & $\begin{array}{c}77,8 \% \\
16,7 \% \\
5,5 \%\end{array}$ \\
\hline 4 & 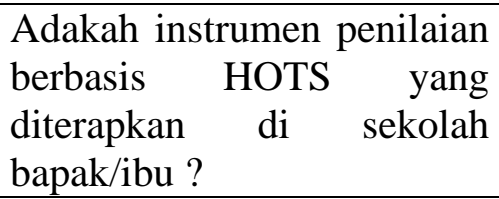 & $\begin{array}{l}\text { a. Ada } \\
\text { b. Tidak ada } \\
\text { c. Ada, Masih } \\
\text { kurang }\end{array}$ & $\begin{array}{l}19,4 \% \\
22,3 \% \\
58,3 \%\end{array}$ & $\begin{array}{l}\text { a. Ada } \\
\text { b. Tidak ada } \\
\text { c. Ada, Masih } \\
\text { kurang }\end{array}$ & $\begin{array}{l}19,4 \% \\
22,3 \% \\
58,3 \%\end{array}$ \\
\hline 5 & $\begin{array}{l}\text { Dari mana Bapak/Ibu } \\
\text { memperoleh intrumen } \\
\text { penilaian yang akan } \\
\text { digunakan dalam } \\
\text { evaluasi pembelajaran? }\end{array}$ & $\begin{array}{l}\text { a. Buku teks } \\
\text { b. Internet } \\
\text { c. LKS }\end{array}$ & $\begin{array}{c}27,8 \% \\
63,9 \% \\
8,3 \%\end{array}$ & $\begin{array}{l}\text { a. Buku teks } \\
\text { b. Internet } \\
\text { c. LKS }\end{array}$ & $\begin{array}{c}27,8 \% \\
63,9 \% \\
8,3 \%\end{array}$ \\
\hline 6 & \begin{tabular}{lr}
\multicolumn{2}{l}{ Apakah Bapak/Ibu pernah } \\
menggunakan & soal-soal \\
berbasis HOTS & dalam \\
proses & kegiatan \\
pembelajaran? & \\
\end{tabular} & $\begin{array}{l}\text { a. Sering } \\
\text { b. Kadang- } \\
\text { kadang } \\
\text { c. Jarang }\end{array}$ & $\begin{array}{l}16,7 \% \\
52,8 \% \\
30,5 \%\end{array}$ & $\begin{array}{ll}\text { a. Sering } \\
\text { b. Kadang- } \\
\text { kadang } \\
\text { c. Jarang }\end{array}$ & $\begin{array}{l}16,7 \% \\
52,8 \% \\
30,5 \%\end{array}$ \\
\hline 7 & $\begin{array}{lr}\text { Menurut } & \text { Bapak/Ibu } \\
\text { samakah } & \text { instrumen } \\
\text { penilaian biasa dengan } \\
\text { instrumen penilaian HOTS ? }\end{array}$ & $\begin{array}{l}\text { a. Sama } \\
\text { b. Berbeda } \\
\text { c. Tidak tahu }\end{array}$ & $\begin{array}{l}16,7 \% \\
61,1 \% \\
22,2 \%\end{array}$ & $\begin{array}{l}\text { a. Sama } \\
\text { b. Berbeda } \\
\text { c. Tidak tahu }\end{array}$ & $\begin{array}{c}63,8 \% \\
8,4 \% \\
27,8 \%\end{array}$ \\
\hline 8 & \begin{tabular}{lrr}
\multicolumn{2}{l}{ Ketika } & \multicolumn{2}{r}{ mengembangkan } \\
soal HOTS, hal yang \\
pertama kali dilakukan \\
adalah:
\end{tabular} & $\begin{array}{l}\text { a. Langsung } \\
\text { membuat soal } \\
\text { b. Membuat kisi- } \\
\text { kisi soal } \\
\text { c. Memikirkan } \\
\text { soal yang sulit }\end{array}$ & $\begin{array}{l}11,1 \% \\
66,7 \% \\
22,2 \%\end{array}$ & $\begin{array}{l}\text { a. Langsung } \\
\text { membuat soal } \\
\text { b. Membuat kisi- } \\
\text { kisi soal } \\
\text { c. Memikirkan } \\
\text { soal yang sulit }\end{array}$ & $\begin{array}{l}47,2 \% \\
50 \% \\
2,8 \%\end{array}$ \\
\hline 9 & $\begin{array}{l}\text { Menurut } \\
\text { seberapa penting soal-soal } \\
\text { berbasis HOTS diterapkan } \\
\text { untuk siswa/i di sekolah } \\
\text { bapak/Ibu? }\end{array}$ & $\begin{array}{l}\text { a. Sangat penting } \\
\text { b. Penting } \\
\text { c. Biasa saja }\end{array}$ & $\begin{array}{c}16,7 \% \\
80,5 \% \\
2,8 \%\end{array}$ & $\begin{array}{l}\text { a. Sangat penting } \\
\text { b. Penting } \\
\text { c. Biasa saja }\end{array}$ & $\begin{array}{c}86,11 \% \\
5,5 \% \\
8,4 \%\end{array}$ \\
\hline
\end{tabular}




\section{INTEGRITAS : Jurnal Pengabdian}

Vol 4, No 2, Desember 2020

ISSN $2580-7978$ (cetak) ISSN 2615 - 0794 (online)

Dari beberapa pertanyaan di atas, terlihat peningkatan pemahaman peserta sebelum pelatihan dan sesudah pelatihan diberikan. Sebelum pelatihan dilaksanakan, sebanyak $16,7 \%$ (6 orang) peserta yang sudah paham apa itu soalsoal HOTS dan sebanyak 77,8\% (28 orang) peserta kurang paham serta 5,5\% (2 orang) peserta yang tidak paham apa itu soal-soal HOTS. Namun setelah pelatihan terjadi peningkatan yang sangat signifikan, yakni sebanyak 91\% (33 orang) peserta sudah paham apa itu soal HOTS.

Sebelum pelatihan sebanyak 77,8\% (28 orang) peserta yang tidak dapat membedakan soal-soal HOTS dengan soal-soal biasa, namun setelah diberikan pelatihan hanya $5,5 \%$ ( 2 orang) peserta saja yang tidak dapat membedakan soal HOTS dengan soal biasa.

Peningkatan juga terlihat dari pemahaman peserta tentang karakteristik soalsoal berbasis HOTS, dimana sebelum diberikan pelatihan hanya 2,8\% yang telah paham, namun setelah diberikan pelatihan naik menjadi 77,8\% (28 orang) peserta yang telah paham.

\section{KESIMPULAN}

Dari hasil pengamatan selama berlangsungnya kegiatan pengabdian kepada masyarakat ini, dapat disimpulkan bahwa kegiatan pengabdian kepada masyarakat ini sangat bermanfaat bagi guru-guru SMP di Aceh Utara, yaitu dalam hal:

1. Meningkatkan kompetensi guru-guru SMP di Aceh Utara dalam mendesain soal-soal matematika yang berbasis HOTS

2. Meningkatkan kreativitas guru-guru SMP di Aceh Utara dalam mendesain soal-soal matematika berbasis HOTS yang kontekstual dengan kearifan lokal.

Adapun saran setelah dilaksanakan kegiatan pengabdian pada masyarakat ini, diharapkan kepada guru-guru SMP di Aceh Utara untuk dapat mengenalkan dan menerapkan soal-soal berbasis HOTS di kelas dan disebarluaskan pada teman-teman sejawatnya di Aceh Utara.

\section{UCAPAN TERIMA KASIH}

Terimakasih kepada lembaga penelitian dan pengabdian kepada masyarakat (LPPM) yang telah mendanai kegiatan pengabdian kepada masyarakat tahun 2020. 
INTEGRITAS : Jurnal Pengabdian

Vol 4, No 2, Desember 2020

ISSN $2580-7978$ (cetak) ISSN 2615 - 0794 (online)

Terimakasih kepada guru-guru SMP di Aceh Utara sebagai peserta aktif yang telah mengikuti kegiatan pengabdian kepada masyarakat tahun 2020.

\section{DAFTAR PUSTAKA}

Ariyana, Y., \& Bestary, R. (2018). Buku Pegangan Pembelajaran Berorientasi pada Keterampilan Berpikir Tingkat Tinggi. Direktorat Jenderal Guru dan Tenaga Kependidikan Kementerian Pendidikan dan Kebudayaan Hak.

Deni, K. H. (2008). Seluk-Beluk Profesi Guru. Bandung : PT Pribumi Mekar.

Fanani, M. Z. (2018). Strategi Pengembangan Soal Higher Order Thinking Skills (HOTS) Dalam Kurikulum 2013. Edudeena, 2(1), 57-76. https://doi.org/10.30762/ed.v2i1.582

Kunandar. (2007). Guru Profesional Implementasi Kurikulum Tingkat Satuan Pendidikan (KTSP) dan Persiapan Menghadapi Sertifikasi Guru. Jakarta: PT. RajaGrafindo Persada.

Mulyasa. (2005). Menjadi Guru Profesional: Menciptakan Pembelajaran Kreatif dan Menyenangkan, Bandung: Rosdakarya.

Novauli, F. (2015). Jurnal Administrasi Pendidikan Pascasarjana Universitas Syiah Kuala. ISSN 2302-0156. Volume 3, No. 1, Februari 2015. Hal. 45-67.

Purwanto, Budi. (2004). Fisika Dasar Teori dan Implementasinya. Solo : PT Tiga Serangkai Pustaka Mandiri.

Rohim, Dhina, C. (2019). Strategi Penyusunan Soal Berbasis HOTs pada Pembelajaran Matematika SD. BRILIANT: Jurnal Riset dan Konseptual Volume 4 Nomor 4, Hal. 436- 450

Rusman. (2011). Model-model Pembelajaran-Mengembangkan Profesionalisme Guru. Jakarta: PT.Raja grafindo Persada.

Sagala,S., (2009). Kemampuan Profesional Guru dan Tenaga Kependidikan. Bandung: Alfabeta

Sumaryanta. (2018). Penilaian HOTS dalam Pembelajaran Matematika. Indonesian Digital Journal of Mathematics and Education, 8(8), 500509.https://doi.org/10.31227/osf.io/zypex

Talajan, G. (2012). Menumbuhkan Kreativitas \& Prestasi Guru. Yogyakarta: LaksBang PRESSindo.

Uno, H. B. (2007). Profesi Kependidikan. Jakarta: PT Bumi Aksara.

Munandar, U. (2004). Pengembangan Kreativitas Anak Berbakat. Jakarta: Rineka Cipta. 